\title{
Characteristics of Principals and Schools in the Dinaric Region
}

\author{
Beti Lameva, Ženeta Džumhur, and Mojca Rožman
}

\begin{abstract}
The principal in a school is a manager and school leader who is responsible for advancement and implementation of various processes in the school. They take responsibility for compliance and accountability, support the teaching staff in their professional activities, and aim to build and maintain a school environment that promotes student achievement and good school-community relations. An important element of IEA's Trends in International Mathematics and Science Study (TIMSS) is the research into the home, community, school, and student factors associated with student achievement in mathematics and science. To accomplish this, data about the contexts for learning are collected through questionnaires completed by students and their parents/guardians, teachers, and school principals. Analysis of data from TIMSS 2019 for participants in the Dinaric region (Albania, Bosnia and Herzegovina, Croatia, Kosovo, Montenegro, North Macedonia, and Serbia) was used to determine whether the level of education, years of experience of the principal, the location of the school, and/or school composition have significant effects on student achievement and thus potentially identify elements that facilitate academic achievement among students. The TIMSS school questionnaire asks principals to provide assessments of the literacy and numeracy skills of students when they first start schooling, the socioeconomic background of the students attending the school, the availability of instructional resources, the school's emphasis on academic success, and discipline and school safety. While previous research has suggested that principals' years of experience and educational attainment are positively related to student achievement, there was little evidence for this in this regional sample of education systems. In three of the seven TIMSS participants in the Dinaric region, students from schools with a
\end{abstract}

B. Lameva (凶)

National Examination Centre, Skopje, Republic of Macedonia

e-mail: betilameva@dic.edu.mk

Ž. Džumhur

Agency for Preschool, Primary and Secondary Education, Sarajevo, Bosnia and Herzegovina e-mail: zaneta.dzumhur@aposo.gov.ba

M. Rožman

International Association for the Evaluation of Educational Achievement (IEA), Hamburg, Germany

e-mail: Mojca.rozman@iea-hamburg.de

(C) International Association for the Evaluation of Educational Achievement (IEA) 2022

B. Japelj Pavešić et al. (eds.), Dinaric Perspectives on TIMSS 2019, IEA Research

for Education 13, https://doi.org/10.1007/978-3-030-85802-5_8 
socioeconomically more affluent student body tended to achieve higher scores in mathematics and science. In four of the seven TIMSS participants, schools that placed strong emphasis on academic success tended to have higher levels of student achievement. The findings suggest that school principals in the region can best improve their students' achievement by focusing on encouraging student motivation and providing additional instructional resources for socioeconomically disadvantaged children.

Keywords Achievement $\cdot$ Leadership $\cdot$ Mathematics $\cdot$ School education $\cdot$ School principals $\cdot$ Science $\cdot$ Trends in International Mathematics and Science Study (TIMSS)

\section{Introduction}

What organizational features make a school a better place for teachers to teach and for students to learn has always been a very important question. Hoy (2012) identified three characteristics of schools that made a positive difference to student achievement after controlling for socioeconomic status (SES), namely (1) collective efficacy, (2) collective trust in parents and students, and (3) the academic emphasis of the school. In addition, school location can play an important role in education; schools in urban areas differ from schools in rural areas, and usually the former are associated with higher student performance. There are several explanations for this. Urban schools are usually larger, enjoy greater responsibility for resource allocation, and are less likely to experience staff shortages. Urban schools tend to have a higher proportion of qualified teachers, and higher student to teacher ratios than schools in rural areas and towns (OECD [Organisation for Economic Cooperation and Development], 2013; for additional research into the effects of school location, see also chapter "Scaffolding the Learning in Rural and Urban Schools: Similarities and Differences").

In public schools (state-funded), principals are also responsible for implementing standards, programs, and regulations set by higher educational authorities (such as government ministries) and related bodies. The role that principals play in schools is very important, as they are not only the administrators but also the initiators of many processes. As school managers, they should be school leaders who improve school processes and support high achievement among students (Malere \& Ozola, 2019). Principals serve as the public representatives of their school. Elementary school principals provide direction and manage the overall operations of schools. They set and oversee academic goals, and ensure that teachers have the equipment and resources to meet those goals. Principals may establish and supervise additional programs in their school, such as counseling, extracurricular activities, and beforeand after-school daycare. Principals clearly have an important management role, including responsibilities for teachers, curricula, and school budgets. They further facilitate cooperation with the students' parents and the local community by listening to and addressing their concerns. Research has indicated that school environment 
created by the principal may have a significant influence on students' mathematics and reading achievement (Alhosani et al., 2017; Dhuey \& Smith, 2014).

Seven participants from the Dinaric region took part in TIMSS 2019, namely Albania, Bosnia and Herzegovina, Croatia, Kosovo, ${ }^{1}$ Montenegro, North Macedonia, and Serbia. Across the Dinaric region, elementary school principals typically undertake the following activities:

- manage school activities and staff, including teachers and support personnel;

- establish and oversee class schedules;

- implement and maintain curriculum standards;

- observe and evaluate teachers' performance;

- meet with parents and teachers to discuss students' progress and behavior;

- assess and prepare reports on test scores and other student achievement data;

- organize professional development programs and workshops for staff;

- establish and coordinate security procedures for students, staff, and visitors; and

- manage the school budget, including the provision of school supplies, and maintenance.

Some research has suggested that the "formal" characteristics of principals may play an important role in student attainment. For example, a systematic review by Osborne-Lampkin et al. (2015) reported that principals' years of experience and educational attainment were positively related to student achievement.

\subsection{Framing the Research Questions}

Our research analyses focus on connecting the professional characteristics of principals with school characteristics across the Dinaric region. We examined the relationship of these characteristics with student achievement to explore differences and similarities across the region.

Our review of the TIMSS 2019 regional data was designed to address four critical questions:

(1) What are the licensing or certification requirements for principals across the Dinaric region?

(2) What is the qualification level of principals? Is there an association between student mathematics and science achievement and principals' education levels across the Dinaric region?

(3) How many of years of professional experience do principals across the region have generally? Is there an association between student mathematics and science achievement scores and this experience?

\footnotetext{
${ }^{1}$ This designation is without prejudice to positions on status, and is in line with UNSCR 1244/1999 (United Nations, 1999) and the International Court of Justice (ICJ) Opinion on the Kosovo declaration of independence (ICJ, 2010).
} 
(4) Do school characteristics (school location, school composition by socioeconomic background, and school emphasis on academic success) differ among Dinaric education systems? Are these characteristics related to variation in student achievement?

\section{Variables}

For our research analyses, we selected relevant data collected by the TIMSS 2019 student school questionnaires, the latter completed by school principals (Table 1; for more details on the questionnaires, see TIMSS \& PIRLS International Study Center, 2018). We analyzed the associations between these variables and student achievement scores in the TIMSS 2019 mathematics and science assessments using basic and advanced methods to estimate percentages, means, correlations, and develop regression models. We conducted statistical computations using established standard procedures for handling data from large-scale assessments (see Sect. 5 for more details on the data sources, and the analysis methods and tools that we used).

In addition to the data collected by the TIMSS 2019 study, we collected information about specific requirements for principals across the region by preparing a short additional questionnaire that we distributed to national research coordinators in the Dinaric region. We used this questionnaire to collect information on:

- relevant qualifying criteria for school principals;

- certification for school principals;

- models of professional development for school principals; and

- number of years that school principals or school directors have held their mandate.

\section{Results}

\subsection{Characteristics of School Principals and Relation to Student Achievement}

In the Dinaric region, principals generally required at least five to eight years work experience in the education sector after acquiring their teaching degree before becoming a school principal, except in Kosovo where only three years of work experience were required (Table 2). By law, in Montenegro, Bosnia and Herzegovina, North Macedonia, and Kosovo, school principals require a recognized university degree. In Croatia, school principals require a postgraduate university degree, with a total of at least eight years of work experience in schools or other institutions in the education system or in state administration bodies responsible for education (where at least five years should be acquired in education in school institutions). Albania, Montenegro, North Macedonia, and Serbia have also implemented a model of professional development for school principals. Principals must complete a specialized 
Table 1 List of variables and scales used in our analyses

\begin{tabular}{|c|c|c|c|}
\hline Variable & Description & $\begin{array}{l}\text { Values/response } \\
\text { options }\end{array}$ & Reference \\
\hline $\begin{array}{l}\text { Principals' years of } \\
\text { experience }\end{array}$ & $\begin{array}{l}\text { Years of experience as } \\
\text { a principal }\end{array}$ & Number of years & $\begin{array}{l}\text { Fishbein et al. (2021) } \\
\text { Supplement 1, p. } 100\end{array}$ \\
\hline $\begin{array}{l}\text { Principals' } \\
\text { education }\end{array}$ & $\begin{array}{l}\text { The highest completed } \\
\text { level of principals' } \\
\text { formal education }\end{array}$ & $\begin{array}{l}\text { Did not complete } \\
\text { bachelor's or } \\
\text { equivalent level } \\
\text { Bachelor's or } \\
\text { equivalent level } \\
\text { Master's or equivalent } \\
\text { level } \\
\text { Doctor or equivalent } \\
\text { level }\end{array}$ & $\begin{array}{l}\text { Fishbein et al. (2021) } \\
\text { Supplement 1, p. } 100\end{array}$ \\
\hline School location & $\begin{array}{l}\text { Size of population in } \\
\text { area of school location }\end{array}$ & $\begin{array}{l}\text { More than } 500,000 \\
\text { people } \\
100,001 \text { to } 500,000 \\
\text { people } \\
50,001 \text { to } 100,000 \\
\text { people } \\
30,001 \text { to } 50,000 \\
\text { people } \\
15,001 \text { to } 30,000 \\
\text { people } \\
3001 \text { to } 15,000 \text { people } \\
3000 \text { people or fewer }\end{array}$ & $\begin{array}{l}\text { Fishbein et al. (2021) } \\
\text { Supplement 1, p. } 95\end{array}$ \\
\hline $\begin{array}{l}\text { School emphasis on } \\
\text { academic success } \\
\text { scale }^{\mathrm{a}}\end{array}$ & $\begin{array}{l}\text { The scale is based on } \\
\text { thirteen items that } \\
\text { measure the principal's } \\
\text { perception of students', } \\
\text { parents' and teachers' } \\
\text { focus on student } \\
\text { achievement }\end{array}$ & $\begin{array}{l}\text { Higher values represent } \\
\text { more emphasis on } \\
\text { academic success }\end{array}$ & $\begin{array}{l}\text { Martin et al. (2020) } \\
\text { p. } 16.124\end{array}$ \\
\hline $\begin{array}{l}\text { Home resources for } \\
\text { learning scale }\end{array}$ & $\begin{array}{l}\text { Based on students' and } \\
\text { parents' reports } \\
\text { regarding the } \\
\text { availability of five } \\
\text { resources: } \\
\text { - Number of books in } \\
\text { the home (students) } \\
\text { - Number of home } \\
\text { study support } \\
\text { (students) } \\
\text { - Number of children's } \\
\text { books in the home } \\
\text { (parents) } \\
\text { - Highest level of } \\
\text { education of either } \\
\text { parent (parents) } \\
\text { - Highest level of } \\
\text { occupation of either } \\
\text { parent (parents) }\end{array}$ & $\begin{array}{l}\text { Higher values mean } \\
\text { more home resources } \\
\text { Index: Many resources, } \\
\text { Some resources, Few } \\
\text { resources }\end{array}$ & $\begin{array}{l}\text { Martin et al. (2020) } \\
\text { p. } 16.39\end{array}$ \\
\hline
\end{tabular}


Table 1 (continued)

\begin{tabular}{|c|c|c|c|}
\hline Variable & Description & $\begin{array}{l}\text { Values/response } \\
\text { options }\end{array}$ & Reference \\
\hline $\begin{array}{l}\text { School composition } \\
\text { by socioeconomic } \\
\text { background }\end{array}$ & $\begin{array}{l}\text { Principal's report on } \\
\text { the share of students in } \\
\text { the school coming } \\
\text { from: } \\
\text { - Economically } \\
\text { disadvantaged homes } \\
\text { - Economically } \\
\text { affluent homes } \\
\text { Response options: } \\
0-10 \%, 11-25 \% \text {, } \\
26-50 \% \text {, more than } \\
50 \%\end{array}$ & $\begin{array}{l}\text { More affluent: Schools } \\
\text { where more than } 25 \% \\
\text { of the student body } \\
\text { comes from } \\
\text { economically affluent } \\
\text { homes and not more } \\
\text { than } 25 \% \text { from } \\
\text { economically } \\
\text { disadvantaged homes } \\
\text { More disadvantaged: } \\
\text { Schools where more } \\
\text { than } 25 \% \text { of the student } \\
\text { body comes from } \\
\text { economically } \\
\text { disadvantaged homes } \\
\text { and not more than } 25 \% \\
\text { from economically } \\
\text { affluent homes } \\
\text { Neither more affluent } \\
\text { nor more } \\
\text { disadvantaged: All } \\
\text { other possible response } \\
\text { combinations }\end{array}$ & $\begin{array}{l}\text { Fishbein et al. (2021) } \\
\text { Supplement 3, p. } 19\end{array}$ \\
\hline
\end{tabular}

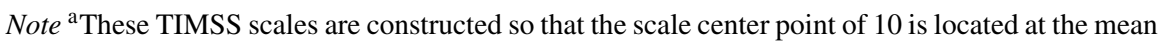
score of the combined distribution of all TIMSS 2019 grade four participants. The units of the scale are chosen so that the standard deviation of the distribution corresponds to two scale score points. For more information on scale construction, please see Yin and Fishbein (2020)

Table 2 Overview of qualifications required for a school principal position in the Dinaric region

\begin{tabular}{l|l|l|l|l}
\hline $\begin{array}{l}\text { Education } \\
\text { system }\end{array}$ & $\begin{array}{l}\text { Minimum years } \\
\text { of experience in } \\
\text { education }\end{array}$ & $\begin{array}{l}\text { Does principal } \\
\text { need to complete a } \\
\text { specialized school } \\
\text { leadership training } \\
\text { program }\end{array}$ & $\begin{array}{l}\text { Is there an } \\
\text { established model } \\
\text { of professional } \\
\text { development for } \\
\text { school principals? }\end{array}$ & $\begin{array}{l}\text { Number of years } \\
\text { that the school } \\
\text { principal } \\
\text { appointment lasts }\end{array}$ \\
\hline Albania & 5 & Yes & Yes & Unlimited \\
\hline $\begin{array}{l}\text { Bosnia and } \\
\text { Herzegovina }\end{array}$ & 5 & No & No & 4 \\
\hline Croatia & 8 & No & No & 5 \\
\hline Kosovo & $3^{\mathrm{a}}$ & Yes & No & 4 \\
\hline Montenegro & 5 & Yes & Yes & 4 \\
\hline $\begin{array}{l}\text { North } \\
\text { Macedonia }\end{array}$ & 5 & Yes & Yes & 4 \\
\hline Serbia & 8 & Yes & Yes & 4 \\
\hline
\end{tabular}

Note ${ }^{\text {a } I n} 2019$, this changed from three to four years 
school leadership training program in Albania, Kosovo, Montenegro, North Macedonia, and Serbia; in Albania, Montenegro, North Macedonia, and Serbia, successful completion of this program gives school principals a license, which indicates that they have met the required level of general and professional competencies. In all education systems in Dinaric region, the school principal is selected after an open call has been issued, and, in general, school principals in the Dinaric region are appointed for a term of four years, although, in Croatia, their appointment is for five years and, in Albania, for an unlimited period. In Croatia and Serbia, principals can be reappointed multiple times; in Serbia, their prior position in school is held for two terms. In Bosnia and Herzegovina, Kosovo, Montenegro, and North Macedonia, the school principal can be appointed to a school no more than twice consecutively. All this is regulated by national legislation.

Across the Dinaric region, Croatia reported the highest percentage of school principals with a master's or a doctorate degree level qualification (96\%), followed by Albania (51\%) (Table 3). In most other systems in the region, the majority of schools are managed by a principal holding a degree at bachelor level or an equivalent (Table 3).

For each level of principal qualification, we also analyzed the related percentages of students and their achievement differences in mathematics and science (see Table S.14 in the supplementary materials available for download at www.iea.nl/public ations/RfEVol13). We found that the association between student achievement and principal education was only significant in Montenegro, where grade four students in schools where principals had completed a postgraduate degree tended to have a significantly higher achievement than students in schools where principals had only completed a bachelor's degree or equivalent. They obtained, on average, 16 score

Table 3 Percentage of principals by educational level

\begin{tabular}{l|l|l|l|l|l|l}
\hline \multirow{2}{*}{ Education system } & \multicolumn{3}{l}{ Percentage of school principals who: } \\
\cline { 2 - 7 } & \multicolumn{2}{l}{$\begin{array}{l}\text { Did not complete } \\
\text { bachelor's degree }\end{array}$} & $\begin{array}{l}\text { lompleted bachelor's } \\
\text { degree or equivalent } \\
\text { but not a postgraduate } \\
\text { degree }\end{array}$ & $\begin{array}{l}\text { Completed } \\
\text { postgraduate } \\
\text { university degree }\end{array}$ \\
\hline Albania & 4 & $(1.6)$ & 45 & $(4.8)$ & 51 & $(5.0)$ \\
\hline Bosnia \& Herzegovina & 7 & $(1.9)$ & 77 & $(3.3)$ & 16 & $(3.0)$ \\
\hline Croatia & 1 & $(0.6)$ & 3 & $(2.8)$ & 96 & $(2.9)$ \\
\hline Kosovo & 14 & $(3.8)$ & 53 & $(5.3)$ & 33 & $(5.6)$ \\
\hline Montenegro & 7 & $(2.3)$ & 78 & $(3.5)$ & 15 & $(2.8)$ \\
\hline North Macedonia & 1 & $(0.8)$ & 78 & $(3.9)$ & 21 & $(4.0)$ \\
\hline Serbia ${ }^{\text {a,1 }}$ & 2 & $(1.6)$ & 65 & $(5.5)$ & 33 & $(5.5)$ \\
\hline
\end{tabular}

Notes Standard errors appear in parentheses

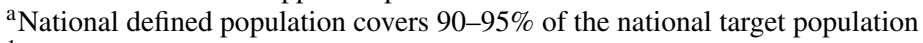

${ }^{1}$ For Serbian principals that graduated after 2005, a postgraduate master's degree is obligatory, according to Serbian law (Teodorović et al., 2019) 
points more in the TIMSS grade four mathematics test and 14 score points more in the TIMSS grade four science test.

One of the primary development strategies for principals is experience acquired during the course of their work, with a general expectation that principals become more effective with increased experience working in a position of that level. On average, across the Dinaric region, principals had less experience than the international TIMSS average (10 years); principals in North Macedonia had notably low levels of experience, while Serbia reported the highest average (Fig. 1; for a more detailed analysis, see Table S.15 in the supplementary materials available for download at www.iea.nl/publications/RfEVol13).

When we analyzed the percentage of students by their principal's number of years of experience, we found that, in North Macedonia, a staggering 71 percent of students were learning in primary schools managed by principals that had less than five years of experience (Fig. 2). This percentage was also significant in Kosovo $(34 \%)$ and Bosnia and Herzegovina (57\%). While Albania had the lowest percentage of principals with less than five years of experience, 28 percent of grade four students still had a principal with little experience of the role. The TIMSS international average was 31 percent; students in the Dinaric region are thus more likely to have less experienced principals than students in other parts of the world. Looking at the same topic from another angle, only about nine percent of students in North Macedonia learn in schools managed by principals with at least 10 years of experience, which is lower than in other systems in the region (13\% in Bosnia and Herzegovina, and $>30 \%$ in Croatia, Kosovo, Serbia, and Montenegro).

However, we found that the TIMSS 2019 grade four data for the Dinaric region did not provide any evidence of a relationship between student achievement and principals' work experience. Calculating the correlation coefficient between the number of years of experience as a principal with the achievement of the students yielded

Fig. 1 Average number of years of experience of school principals

Note In Kosovo and Serbia, the national defined population covers $90-95 \%$ of the national target population

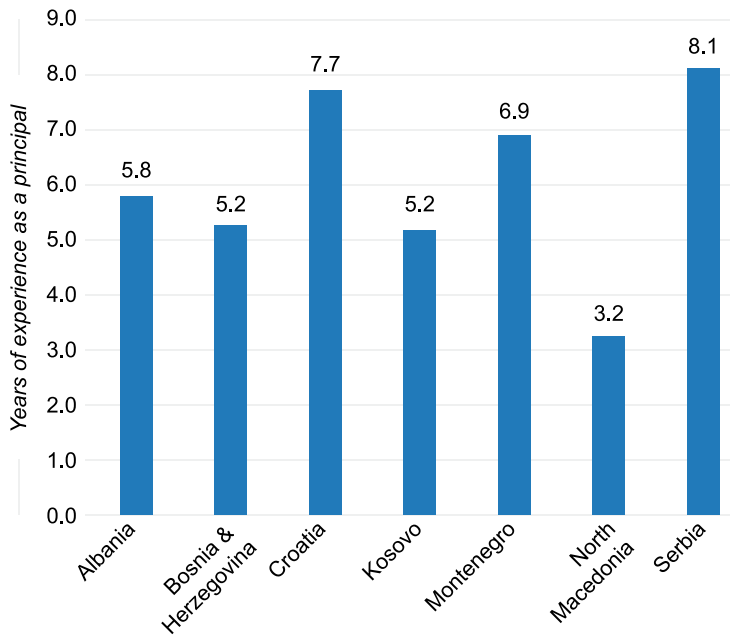




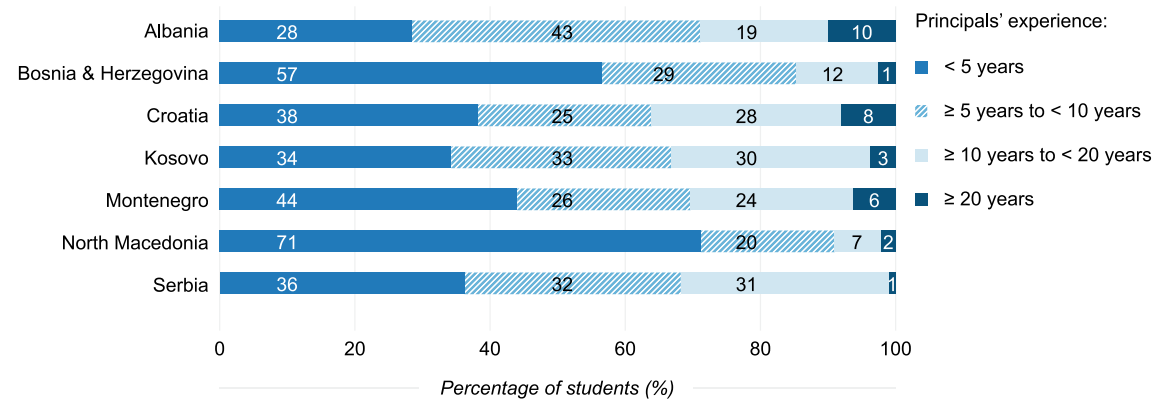

Fig. 2 Percentage of grade four students by their principal's number of years of experience Note In Kosovo and Serbia, the national defined population covers $90-95 \%$ of the national target population

no statistically significant results. Earlier research on this topic is ambiguous. Our findings are in agreement with some studies, where the data suggested that the experience of principals had no close relationship with academic achievement of students (Brockmeier et al., 2013; Gentilucci \& Muto, 2007). In contrast, Dhuey and Smith (2014) reported that principal characteristics had significant effects on student achievement in mathematics and reading, and identified a weak relationship between principals' levels of education and student test scores.

\subsection{Characteristics of School}

A variety of factors contribute to student achievement in mathematics and science, including student behaviors and student, teacher, and school characteristics. We focused on the school characteristics of school location, school composition by socioeconomic background, and school emphasis on academic success.

When comparing education systems across the Dinaric region, formative characteristics are important for contextualizing the findings. The number of people who live in the city, town, or area where the school is located may have an impact on students achievements in the Dinaric region. The Dinaric region generally has low levels of urbanization, and at least two-thirds of the region's students attend schools located in villages or small towns. However, there is still considerable variation in school locations across the region (Fig. 3). In Albania and Kosovo, a third of students attend a school located in an area with 3000 people or less, while, conversely, nearly a third of students in Serbia learn in schools located in a place with more than 100,000 people (Fig. 3).

We investigated whether student achievement was related to school location by comparing the TIMSS mathematics and science achievement of grade four students in schools in areas with $>30,000$ people to that of grade four students in schools in areas with $\leq 30,000$ people (Table 4). Our results indicated that students from bigger 


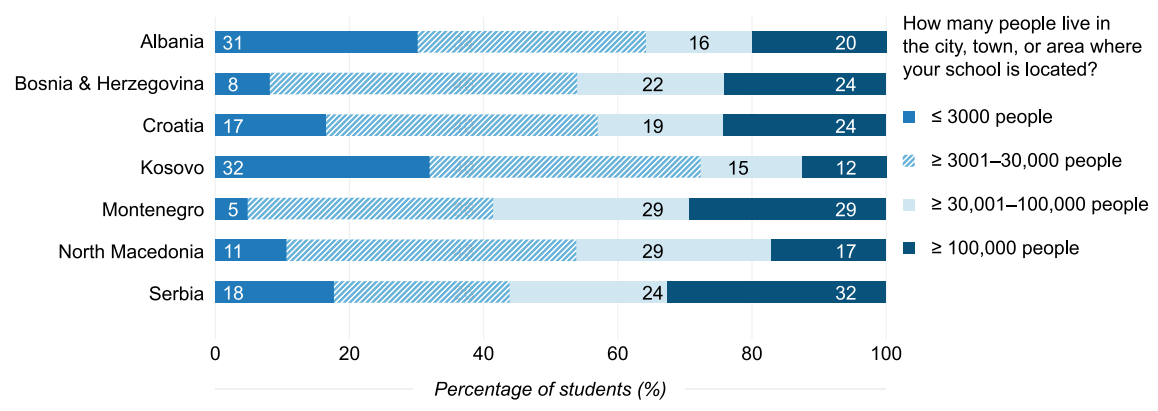

Fig. 3 Percentage of students by school location

Note In Kosovo and Serbia, the national defined population covers $90-95 \%$ of the national target population

Table 4 Mathematics and science achievement difference by school location

\begin{tabular}{|c|c|c|c|c|}
\hline \multirow{3}{*}{$\begin{array}{l}\text { Education system } \\
\text { Albania }\end{array}$} & \multicolumn{4}{|c|}{ Difference in student achievement } \\
\hline & \multicolumn{2}{|c|}{ Mathematics achievement } & \multicolumn{2}{|c|}{ Science achievement } \\
\hline & 32 & $(7.2)$ & 34 & $(7.1)$ \\
\hline Bosnia \& Herzegovina & 14 & $(5.6)$ & 14 & $(5.8)$ \\
\hline Croatia & 13 & $(4.4)$ & 13 & $(3.5)$ \\
\hline Kosovo $^{a}$ & -6 & $(7.0)$ & -4 & $(8.5)$ \\
\hline Montenegro & 2 & $(3.1)$ & -1 & (3.5) \\
\hline North Macedonia & 31 & $(11.8)$ & 39 & $(12.9)$ \\
\hline Serbia $^{\mathrm{a}}$ & 38 & $(5.4)$ & 37 & $(5.7)$ \\
\hline
\end{tabular}

Notes Positive values indicate higher achievement in areas with $>30,000$ people compared to areas with $\leq 30,000$ people. Statistically significant $(p<0.05)$ differences are shown in bold. Standard errors appear in parentheses

${ }^{a}$ National defined population covers $90-95 \%$ of the national target population

cities achieved higher scores than their peers in smaller cities or rural areas; the achievement differences for both mathematics and science were significant across most of the Dinaric region, except for Kosovo and Montenegro. This difference was most pronounced in Albania, North Macedonia, and Serbia, where it exceeded 30 points for both mathematics and science (this corresponds to one-third of the standard deviation of the achievement scale score metric).

There may be multiple reasons for similar clustering effects in the Dinaric region, for example, social segregation of residential areas (in combination with the tendency for children to attend nearby schools), fees for schools, lack of incentives for teachers to elect to work in more challenging areas, and/or better equipment in affluent schools because parents make additional financial contributions.

The social background of families is often reflected in the student intake of schools. Parents with similar backgrounds tend to send their children to schools where they will meet similar children (Cahill, 2009); this can boost the school-level effect on 
learning because children in more affluent schools may already start school with a higher "knowledge baseline" as a consequence of parental factors. We used the school principal responses about the socioeconomic background of the student body to group schools into three categories: "more affluent," "neither more affluent nor more disadvantaged," and "more disadvantaged" (Fig. 4).

We noted that students from different backgrounds seemed to be strongly segregated in many schools in the Dinaric region (Fig. 4). The high percentage of students learning in disadvantaged schools in Albania is particularly noteworthy (almost half of Albania's grade four students attend such schools). In Croatia, the comparable percentage was only 13 percent, while 57 percent of grade four students were reported as attending more affluent schools. In North Macedonia, only 10 percent of students attended "neither more affluent nor more disadvantaged" schools, but 66 percent attended more affluent schools.

We compared average student achievement scores for grade four students from schools with a more affluent student body with those of students from schools with a more disadvantaged student body (Fig. 5). The results indicated that students in more affluent schools tended to achieve higher mathematics and science scores in TIMSS 2019. These differences were generally significant, except in Bosnia and Herzegovina; in Kosovo, only the difference in mathematics achievement was significant. In Croatia, Montenegro, and Serbia, the difference in both subjects was around 20 points, but, in Albania and North Macedonia, the difference exceeded 39 score points, amounting to almost half a standard deviation of the scale metric.

School emphasis on academic success generally plays an important role in supporting or stimulating students in their learning, and implies effective teaching, a motivated work environment, and high levels of expectation for student success.

In TIMSS 2019, principals were asked to report on their school's emphasis on academic success. The TIMSS scale "school emphasis on academic success" (SEAS) (see Table 1) is related to a number of similar items aimed at measuring aspects of the school's emphasis on academic success and the degree of support offered by

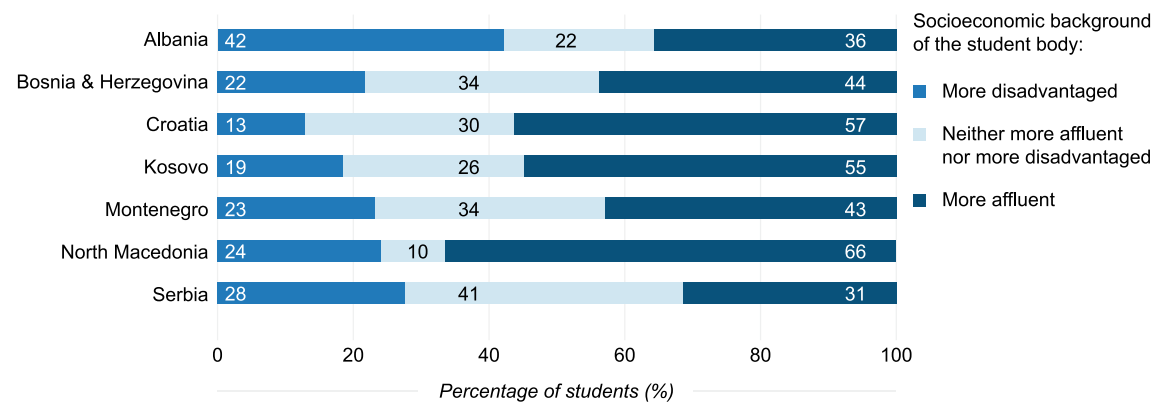

Fig. 4 School composition by principals' assessments of the socioeconomic background of the school's student body

Notes In Kosovo and Serbia, the national defined population covers $90-95 \%$ of the national target population. In Kosovo, data were available for $\geq 50 \%$ but $<70 \%$ of the students 


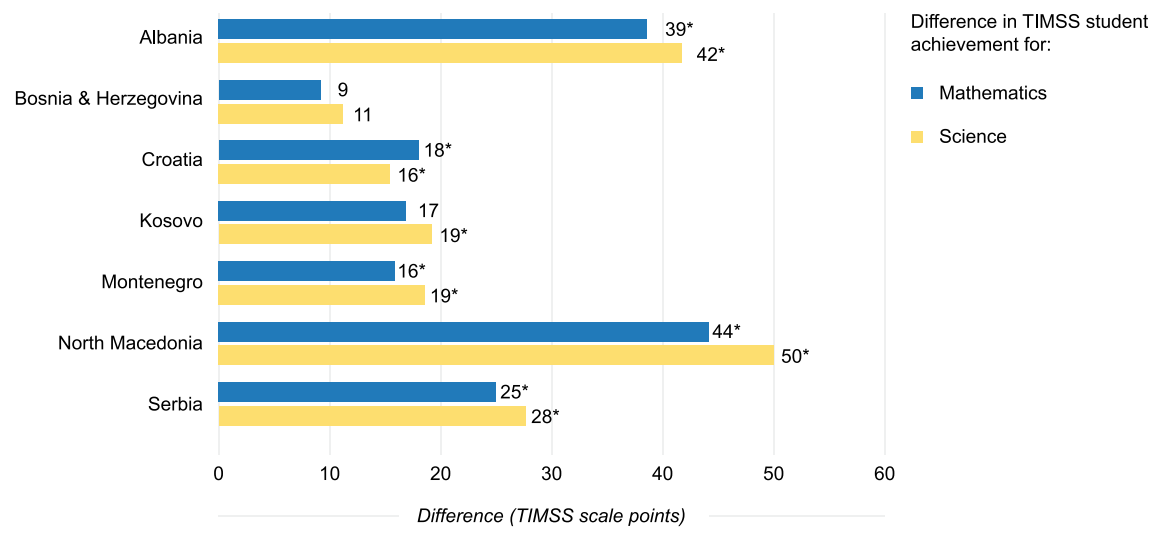

Fig. 5 Difference in grade four student achievement scores by school socioeconomic background Notes ${ }^{*}$ Statistically significant $(p<0.05)$ differences. Positive values indicate higher achievement in more affluent schools compared to more disadvantaged schools. In Kosovo and Serbia, the national defined population covers $90-95 \%$ of the national target population

the school organization and the school environment. Internationally, students who were classified as attending a school with "high or very high emphasis on academic success" are those with a scale score greater than or equal to 9.2. Students who were classified as attending a school with "medium emphasis on academic success" had a score lower than 9.2 (Table 5).

Overall, more than half of students in the region attended schools where principals reported there was a "very high" or "high" emphasis on academic success as part of the school's culture (Fig. 6). The average scale score across the Dinaric region ranged from 9.3 in North Macedonia to 10.3 in Montenegro (Table 5).

We analyzed the correlation between SEAS and grade four student achievement across the region (Table 5). This correlation was very weak, but positive in all participating education systems in the region for both subjects. The correlation coefficients

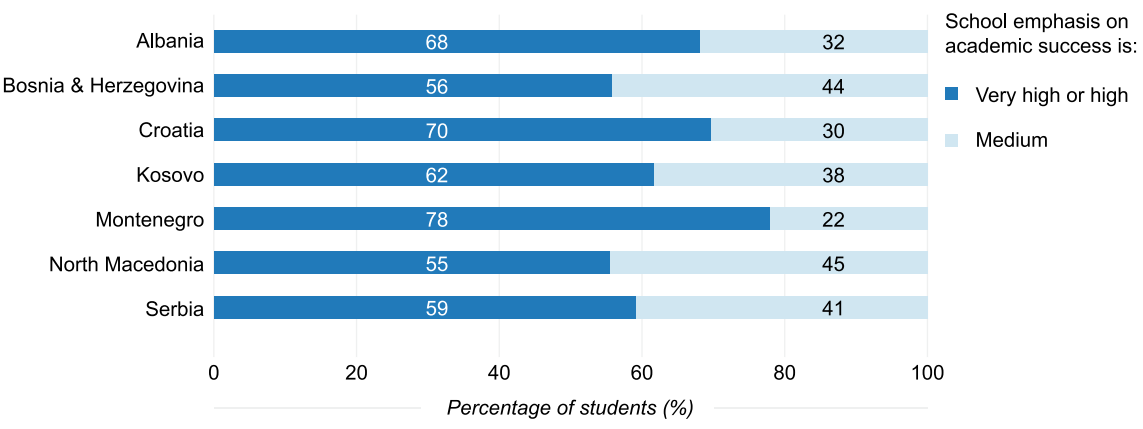

Fig. 6 Percentages of students attending schools with different emphasis levels on academic success, based on principals' assessments of their school culture 
Table 5 School emphasis on academic success as reported by principals, and its correlation with grade four student achievement in TIMSS 2019

\begin{tabular}{|c|c|c|c|c|c|c|}
\hline \multirow[t]{2}{*}{$\begin{array}{l}\text { Education system } \\
\\
\text { Albania }\end{array}$} & \multicolumn{2}{|c|}{$\begin{array}{l}\text { Average scale } \\
\text { score of the } \\
\text { TIMSS } 2019 \\
\text { school emphasis } \\
\text { on academic } \\
\text { success scale }\end{array}$} & \multicolumn{2}{|c|}{$\begin{array}{l}\text { Correlation with } \\
\text { mathematics } \\
\text { achievement }\end{array}$} & \multicolumn{2}{|c|}{$\begin{array}{l}\text { Correlation with } \\
\text { science achievement }\end{array}$} \\
\hline & 10.2 & $(0.1)$ & 0.21 & $(0.04)$ & 0.22 & $(0.05)$ \\
\hline Bosnia \& Herzegovina & 9.8 & $(0.1)$ & 0.02 & $(0.04)$ & 0.03 & $(0.03)$ \\
\hline Croatia & 10.0 & $(0.1)$ & 0.06 & $(0.04)$ & 0.07 & $(0.04)$ \\
\hline $\mathrm{Kosovo}^{\mathrm{a}}$ & 10.1 & $(0.1)$ & 0.13 & $(0.04)$ & 0.15 & $(0.04)$ \\
\hline Montenegro & 10.3 & $(0.0)$ & 0.02 & $(0.02)$ & 0.03 & $(0.02)$ \\
\hline North Macedonia & 9.3 & $(0.2)$ & 0.21 & $(0.06)$ & 0.23 & $(0.06)$ \\
\hline Serbia $^{\mathrm{a}}$ & 9.6 & $(0.1)$ & 0.14 & $(0.05)$ & 0.14 & $(0.05)$ \\
\hline
\end{tabular}

Notes Statistically significant $(p<0.05)$ correlation coefficients are shown in bold. Standard errors are provided in parentheses

a National defined population covers $90-95 \%$ of the national target population

were statistically significant in Albania, Kosovo, North Macedonia, and Serbia. This is in line with Bandura (1993) and Hoy et al. (2006) who confirmed a strong relationship between academic optimism and student achievement; they further stated that efficacy, trust, and positive academic emphases together produce a powerful force that engenders motivation, creates collective optimism, and channels student behavior toward the accomplishment of high academic goals. Schools with academic optimism create collective beliefs that changes are possible and all students can learn, inspiring a confidence that high academic performance can be achieved.

\section{Conclusions}

We analyzed the characteristics of principals and schools in the Dinaric region and the relationship of these characteristics with academic achievement of grade four students in TIMSS 2019. The focus of any principal is to manage the various processes in the school and support the professional activities of their teachers to create a successful learning environment for students. While we cannot address all aspects of a principal's remit in our analyses, the TIMSS 2019 data provide useful information on their educational levels and number of years of experience as a principal, two factors that have been previously linked to student academic achievement (see Dhuey \& Smith, 2014). While we were unable to identify a statistically significant relationship between these characteristics and grade four student mathematics and science achievement in our analyses of the TIMSS 2019 data, the role of the principal is undoubtedly a critical component in student achievement. They can establish 
a positive academic environment that embraces cognitive, emotional, and behavior elements; the positive interaction of all these elements creates a school culture of academic success.

It is essential that the management of the school creates an environment for learning and expects high achievement from the students because this facilitates and improves the achievement of the students. School principals should establish an environment and culture where all involved parties contribute toward supporting and improving student achievement.

There are also non-malleable factors that shape the learning environments of students. One of them is school location. We found that the level of urbanization of the area surrounding the school can also be related to student achievement. We observed that students in areas with more people demonstrated higher achievement scores in mathematics and science than students from schools located in less populated areas in Albania, Bosnia and Herzegovina, Croatia, North Macedonia, and Serbia (for further investigation into differences between urban and rural areas, see chapter "Scaffolding the Learning in Rural and Urban Schools: Similarities and Differences"). Conditions to promote students' learning tend to be better in urban schools, and this tendency is also reinforced by conditions for learning at home, which significantly correlates with higher student achievement.

The composition of the socioeconomic background of the student body of the school could also be related to grade four student mathematics and science achievement. In general, we found that children from more disadvantaged environments scored lower TIMSS achievement than students from more affluent schools. These differences in student achievement were statistically significant in Albania, Croatia, Kosovo (only for science), Montenegro, North Macedonia, and Serbia.

While, across the Dinaric region, TIMSS 2019 data showed no significant relationships between principal characteristics and student achievement, we caution against underestimating the importance of principals. Although we were unable to empirically prove such relationships, this does not necessarily mean they do not exist, as there may be other characteristics associated with achievement that are not reported by TIMSS, and they may be interrelated and interdependent.

An important indicator in this analysis was school emphasis on academic success (as reported by school principals). We found that the correlation between the school emphasis on academic success (as reported by their principals) and grade four student mathematics and science achievement was positive for all participating systems in the region, and statistically significant in Albania, Kosovo, North Macedonia, and Serbia. It is thus important that schools in the Dinaric region continue to promote an emphasis on academic success. School communities (principals, teachers, parents, and students) need to focus on working together to create a positive school climate that helps to establish students' confidence in their abilities and motivate them to better achievement. 


\section{References}

Alhosani, A., Singh, S., \& Nahyan, M. (2017). Role of school leadership and climate in student achievement. International Journal of Education Management, 31(2), https://doi.org/10.1108/ IJEM-05-2016-0113. https://www.researchgate.net/publication/318254863

Bandura, A. (1993). Perceived self-efficacy in cognitive development and functioning. Educational Psychologist, 28(2), 117-148. https://doi.org/10.1207/s15326985ep2802_3

Brockmeier, L. L., Starr, G., Green, R., Pate, J. L., \& Leech, D. W. (2013). Principal and schoollevel effects on elementary school student achievement.. International Journal of Educational Leadership Preparation, 8, 49-61. https://files.eric.ed.gov/fulltext/EJ1013001.pdf

Cahill, R. (2009). Factors that influence the decisions parents make when choosing a secondary school for their children (Doctoral thesis, Edith Cowan University, Joondalup, Australia). https:// ro.ecu.edu.au/theses $/ 549$

Dhuey, E., \& Smith, J. (2014). How important are school principals in the production of student achievement? Canadian Journal of Economics, 47(2), 634-663.

Fishbein, B., Foy, P., \& Yin, L. (2021). TIMSS 2019 user guide for the international database. TIMSS \& PIRLS International Study Center, Boston College. https://timssandpirls.bc.edu/tim ss2019/international-database/

Gentilucci, J. L., \& Muto, C. C. (2007). Principals' influence on academic achievement: the student perspective. NASSP Bulletin. 91(3), 219-236. https://doi.org/10.1177/0192636507303738

Hoy, W. K. (2012). School characteristic that make a difference for the achievement of all students: A 40-years odyssey. Journal of Educational Administration, 50, 76-97.

Hoy, W. K., Tarter, C. J., \& Woolfolk Hoy, A. (2006). Academic optimism of schools: A force for student achievement. American Educational Research Journal, 43(3), 425-446.

ICJ. (2010). Accordance with International Law of the Unilateral Declaration of Independence in Respect of Kosovo, Advisory Opinion, I.C.J. Reports 2010. International Court of Justice. https:// www.icj-cij.org/public/files/case-related/141/141-20100722-ADV-01-00-EN.pdf

Malere, A., \& Ozola, A. (2019), Role of school principals in high achievement of students. In Rural Environment. Education. Personality (REEP). Proceedings of the International Scientific Conference. Volume 12, 10-11 May 2019, Jelgava, Latvia (pp. 83-93). Latvia University of Life Sciences and Technologies, Faculty of Engineering, Institute of Education and Home Economics. http://bit.ly/REEP_2019_proceedings

Martin, M. O., von Davier, M., \& Mullis, I. V. S. (Eds.). (2020). Methods and procedures: TIMSS 2019 technical report. TIMSS \& PIRLS International Study Center, Boston College. https://tim ssandpirls.bc.edu/timss2019/methods

OECD. (2013). What makes urban schools different? PISA in Focus, No. 28. OECD Publishing. https://doi.org/10.1787/5k4618w342jc-en

Osborne-Lampkin, L., Folsom, J. S., \& Herrington, C.D. (2015). A systematic review of the relationships between principal characteristics and student achievement (REL 2016091). US Department of Education, Institute of Education Sciences, National Center for Education Evaluation and Regional Assistance, Regional Educational Laboratory Southeast. https://www.researchgate.net/publication/286446967_A_systematic_review_of_the_relati onships_between_principal_characteristics_and_student_achievement

TIMSS \& PIRLS International Study Center. (2018). TIMSS 2019 context questionnaires. TIMSS \& PIRLS International Study Center, Boston College. https://timssandpirls.bc.edu/timss2019/que stionnaires/index.html

Teodorović, J., Ševkušić, S., Malinić, D., \& Đelić, J. (2019). Leadership in education: The case of Serbia. In S. Ševkušić, D. Malinić, \& J. Teodorović (Eds.), Leadership in education: Initiatives and trends in selected European countries (pp. 163-180). Institute for Educational Research, Jagodina/Faculty of Education, University of Kragujevac/Hungarian-Netherlands School of Educational Management, University of Szeged. 
United Nations. (1999). Resolution 1244 (1999). Adopted by the Security Council at its 4011th Meeting, on 10 June 1999. United Nations Security Council. https://digitallibrary.un.org/record/ $274488 ? \ln =\mathrm{en}$

Yin, L., \& Fishbein, B. (2020). Creating and interpreting the TIMSS 2019 context questionnaire scales. In M. O. Martin, M. von Davier, \& I. V. S. Mullis (Eds.), Methods and procedures: TIMSS 2019 technical report (pp. 16.1-16.331). TIMSS \& PIRLS International Study Center, Boston College. https://timssandpirls.bc.edu/timss2019/methods/chapter-16.html

Beti Lameva is the head of the Sector for Exams, IT and Research at the National Examination Center in the Republic of North Macedonia. She has more than 20 years of experience in education research, establishing large-scale assessment and high-risk exams, data entry, cleaning, and processing. Beti has also been involved in international studies since TIMSS 1999 as a data manager. She is currently the national research coordinator for the international studies, TIMSS and PISA.

Žaneta Džumhur works for the Agency for Preschool, Primary and Secondary Education, since 2009. She has intense experience in external evaluation at national and international levels. Her professional interests are divided between work on research of student achievement and development of learning outcomes. She is author and co-author of a variety of publications and articles. She is also interested in closer cooperation between schools and different actors in school enviroments.

Mojca Rožman is a research analyst at IEA's Research and Analysis Unit. Her background is in psychology and statistics. She has experience in questionnaire development and scaling of questionnaire data. Her interests are methodology and statistical analysis in international large-scale assessments.

Open Access This chapter is licensed under the terms of the Creative Commons AttributionNonCommercial 4.0 International License (http://creativecommons.org/licenses/by-nc/4.0/), which permits any noncommercial use, sharing, adaptation, distribution and reproduction in any medium or format, as long as you give appropriate credit to the original author(s) and the source, provide a link to the Creative Commons license and indicate if changes were made.

The images or other third party material in this chapter are included in the chapter's Creative Commons license, unless indicated otherwise in a credit line to the material. If material is not included in the chapter's Creative Commons license and your intended use is not permitted by statutory regulation or exceeds the permitted use, you will need to obtain permission directly from the copyright holder.

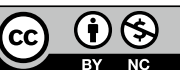

